\title{
Harpin Protein Influence on Fruit Quality Attributes, Ethylene, Respiration, and Minerals in Apples
}

\author{
Esmaeil Fallahi \\ Parma Research and Extension Center, Department of Plant Sciences, University of Idaho, Parma, ID, USA \\ Email: efallahi@uidaho.edu
}

How to cite this paper: Fallahi, E. (2021) Harpin Protein Influence on Fruit Quality Attributes, Ethylene, Respiration, and Minerals in Apples. American Journal of Plant Sciences, 12, 1236-1245.

https://doi.org/10.4236/ajps.2021.128086

Received: July 3, 2021

Accepted: August 8, 2021

Published: August 11, 2021

Copyright $\odot 2021$ by author(s) and Scientific Research Publishing Inc. This work is licensed under the Creative Commons Attribution International License (CC BY 4.0).

http://creativecommons.org/licenses/by/4.0/

\section{(c) (i) Open Access}

\begin{abstract}
The competitive global fruit market mandates production of apples with high quality attributes, particularly fruit color. Harpin Protein (Messenger ${ }^{\circledR}$ ) is shown to trigger resistance to blue mold in apples, but limited information can be found on the effect of this compound on fruit quality. In this study, the impact of Harpin protein on quality attributes of four apple cultivars was studied. "Red Spur Delicious" apple fruit from trees receiving Harpin protein had significantly (about 23\%) better color, earlier ethylene evolution, and higher respiration than those from untreated control trees, while their firmness was not adversely affected. Application of Harpin protein on "Red Chief Delicious" apple improved fruit color and increased fruit size in two locations, and advanced starch degradation pattern in one orchard but reduced fruit firmness in one location. Harpin protein tended (but not significantly) to improve fruit color in "Jonathan" and "Early Spur Rome" but reduced fruit size in "Jonathan" apples. Messenger ${ }^{\circledast}$ increased fruit percentage dry weight and $\mathrm{Fe}$ but decreased fruit $\mathrm{Ca}, \mathrm{Mg}, \mathrm{K}$, and $\mathrm{Zn}$. Improving apple fruit color by Harpin protein could have major impacts on apple industry and warrants further study.
\end{abstract}

\section{Keywords}

Bio-Regulator, Bio-Stimulants, Color Improvement, Employ, Harpin Protein, Messenger

\section{Introduction}

Due to globalization of fruit market and an increase in the volume of fruit production, apple growers face stiff competition. These challenges, combined with 
the increasing awareness of public about the environmental and food safety, mandate production of fruit with high quality, using safe and preferably, natural chemicals.

Growth regulators, like the endogenous hormones that exist in the fruit trees are commonly used in both pome fruit and stone fruit to increase fruit size, color, storability and other quality attributes that are critical to the apple market. These chemicals are often used during growing season as bloom or post-bloom thinners. Apple crops need to be thinned to create a balance between leaf and fruit and reduce biennial bearing habit and to produce marketable fruit, with optimum size and quality attributes [1] [2] [3] [4] [5]. Monocarbamide dihydrogen sulfate (Wilthin) has been used for blossom thinning in apples [2] and stone fruit [5]-[10]. In a comparison of ammonium thiosulfate (ATS), Wilthin, and Endothall, ATS was the best blossom thinner under Washington conditions [5]. Application of gibberellins $\left(\mathrm{GA}_{3}\right)$ on cherries during the stages II-III transition increased fruit size and delayed maturation [11]-[17].

Bio-stimulants, with or without hormonal action, have been used in the past decades, to improve apple fruit quality attributes [2]. Among these bio-stimulants was a commercial compound called Messenger ${ }^{\circledR}$ with 3\% Harpin protein (Eden Bioscience Corp., Woodinville, WA, USA). Today, employ with $1 \%$ Harpin protein, is distributed by Plant Health Care, Inc, Raleigh, NC, USA. Harpin is a class of protein produced in nature by certain bacterial plant pathogens and does not have hormonal action [18]. Harpin protein evokes a natural defense mechanism in plants, analogous to a broad-spectrum immune response in animals. While most pesticides act directly on the target pest, Harpin protein, by contrast, elicits a protective response in the plant that makes it resistant to a wide range of fungal, bacterial, and viral diseases and selected insect populations [18] [19] [20]. Studies revealed that Harpin protein triggers activation of active oxygen species and cell membrane depolarization, which are known to be involved in resistance [21].

When searching for a safe method of controlling diseases, the commercial products Messenger ${ }^{\circledast}$ with 3\% Harpin protein, reduced severity of Phytophthora damages in tomatoes [22] and induced resistance to blue mold in harvested "Red Delicious" [23] [24] [25] and in "McIntosh" and "Empire" apples [25]. Despite the importance of fruit size and potential role of growth regulators on fruit size, little attention has been given to the impact of bio-stimulants such as Harpin protein on apples. Thus, the objective of this project was to study the impacts of Harpin proteins Messenger ${ }^{\oplus}$ formulation) on fruit quality and maturity attributes of apple cultivars in different locations in the Intermountain west region of the United States.

\section{Materials and Methods}

Orchards for this research were chosen from Parma and Payette, Idaho fruit growing regions. Soils in all orchards were sandy loam with a $\mathrm{pH}$ of about 7.4. 
Apple trees on all these studies were, 12 - 14 years old, planted at $3 \times 6 \mathrm{~m}$ spacing, and general cultural practices were similar to those of the Pacific Northwest region [26]. Trees were mature and had a full production in both 2011 and 2012.

In each study during 2011 and 2012, twenty-five rows of trees were used for this study, of which seven rows were sprayed with Messenger ${ }^{\circledast}$ and seven rows were used as untreated control. There were at least three unsprayed rows between rows that received Messenger ${ }^{\varpi}$. The two closest rows of untreated control and Messenger ${ }^{\circledast}$-treated trees (not including guard rows) were used as a block. In each block of un-treated control or Messenger ${ }^{\circledast}$-treated trees, four adjacent trees with uniform crop load were tagged and fruits from these four trees were combined to make a block of composite sample. Thus, each treatment had seven blocks of composite samples, each containing fruit from four trees.

In 2011, a "Red Spur Delicious" orchard at the University of Idaho Pomology Program near Parma, Idaho was used. In this year, Messenger ${ }^{\circledast}$ with $3 \%$ Harpin protein, as the active ingredient, originally extracted from Erwinia amylovora, at a rate of $0.4395 \mathrm{ml}$ formulation/L was sprayed at a rate of $1870.79 \mathrm{~L}$ liquid/ ha. Trees were in full bloom around April 28, 2011, and were sprayed every other week, starting May 8, 2011. So, the first application was 12 days after full bloom. In 2011, the other applications were on May 22, June 8, June 22, and July 7, 2011. The ranges of temperatures during applications were $17.2^{\circ} \mathrm{C}$ to $20^{\circ} \mathrm{C}$ on May 8 , about $21.1^{\circ} \mathrm{C}$ to $22.2^{\circ} \mathrm{C}$ on May $22,17.8^{\circ} \mathrm{C}$ to $20^{\circ} \mathrm{C}$ on June $8,14.4^{\circ} \mathrm{C}$ to $19.4^{\circ} \mathrm{C}$ on June 22 , and $15.6^{\circ} \mathrm{C}$ to $20^{\circ} \mathrm{C}$ on July $7,2011$.

In 2012, four different orchards were used for this project as follows: 1) Red "Chief Delicious" apple orchard in Parma, Idaho; 2) "Chief Delicious" apple orchard in Payette, Idaho; 3) "Jonathan" apple orchard in Parma, Idaho; 4) "Early Spur Rome" apple orchard in Payette, Idaho. In 2012, Messenger ${ }^{\circledast}$ at a rate of $0.70 \mathrm{ml}$ formulation/L was sprayed at a rate of $935.5 \mathrm{~L}$ liquid/ha every other week, starting 10 days after full bloom. "Delicious" and "Jonathan" apples were in full bloom on April 20, 2012, and "Early Spur Rome" apples were in full bloom on April 26, 2012.

In both 2011 and 2012, thirty-four fruits from each tree were picked randomly at commercial harvest time (late September in both years). Fruits were divided into two groups, weighed, and placed in perforated polyethylene bags. Fruits from one bag were tested for various quality attributes at harvest. The second bag of fruit was stored in a regular atmosphere storage at $-1{ }^{\circ} \mathrm{C}$ with about $90 \%$ relative humidity for about 3 months and then evaluated for quality attributes. Fruit quality attributes were measured in both years. Fruit color was rated visually on a scale of $1=20 \%$ pink/red progressively to $5=100 \%$ red. Fruit firmness was measured on three peeled sides of each fruit by a computerized penetrometer. These fruits then were cut and wedges were juiced, and the soluble solids concentration (SSC) was measured by placing three to four drops of juice on a hand-held, temperature-compensated refractometer (Atago N1, Tokyo, Japan) both at harvest and after storage. Stem-end half of the fruit at harvest was dipped in I-KI solution at harvest, and the starch degradation pattern (SDP) for 
each fruit was recorded by comparison with the SDP standard chart developed for apples, ranging from 1.2 (least starch hydrolysis) to 6.0 (most starch hydrolysis). Only results of fruit quality attributes at harvest time are reported here.

In 2011, eight "Red Spur Delicious" fruits per tree were washed with detergent and rinsed with distilled water. A few wedges of each fruit were sampled to make a composite sample for fruit mineral analysis. Fruit tissues were dried at $65^{\circ} \mathrm{C}$, and ground in a grinder (Cyclotec 1093, Teactor, Inc., Hoganas, Sweden) to pass through a 40-mesh screen. Both fresh and dry weights of fruit samples were also recorded and percent dry matter in fruit was calculated. Fruit nitrogen $(\mathrm{N})$ concentration of each sample was measured by tissue combustion, using LECO (FP-528, LECO Corp., St. Joseph, MI). In this process, about $0.2 \mathrm{~g}$ dried fruit tissue from each sample was combusted, and total $\mathrm{N}$ (expressed as percentage of dry weight) was measured. Five grams of each of the dried fruit samples were weighed and ashed at $500^{\circ} \mathrm{C}$ in an ashing furnace for 5 hours. The ashed samples were digested with $10 \%$ nitric acid. The concentration of fruit calcium $(\mathrm{Ca})$, magnesium $(\mathrm{Mg})$, potassium $(\mathrm{K})$, iron $(\mathrm{Fe})$, zinc $(\mathrm{Zn})$, copper $(\mathrm{Cu})$, and manganese $(\mathrm{Mn})$ were measured by atomic absorption spectrophotometry (Perkin-Elmer 1100 B, Norwalk, CT).

Ethylene evolution and respiration $\left(\mathrm{CO}_{2}\right)$ in "Red Spur Delicious" apple of 2011 sampling that kept in a cold storage, were measured in early January of 2012. For these measurements, five apples from each tree were weighed and then placed in $20 \times 28 \times 28.5-\mathrm{cm}$ closed ripening chambers at the University of Idaho Pomology Laboratory (Figure 1). The temperature of the chambers was maintained at $22.8^{\circ} \mathrm{C}$. Air samples with a constant flow rate of $80 \mathrm{~mL} \cdot \mathrm{min}^{-1}$ were drawn from the ripening chambers every $24 \mathrm{~h}$ to measure concentrations of evolved ethylene and carbon dioxide $\left(\mathrm{CO}_{2}\right)$ by gas chromatography. Samples were injected onto a gas chromatograph (Hewlett Packard 5890 Series II, Lionville, PA) equipped with a flame ionization detector and a HayeSep Q, 80/100 packed column (Alltech Inc., Deerfield, IL).

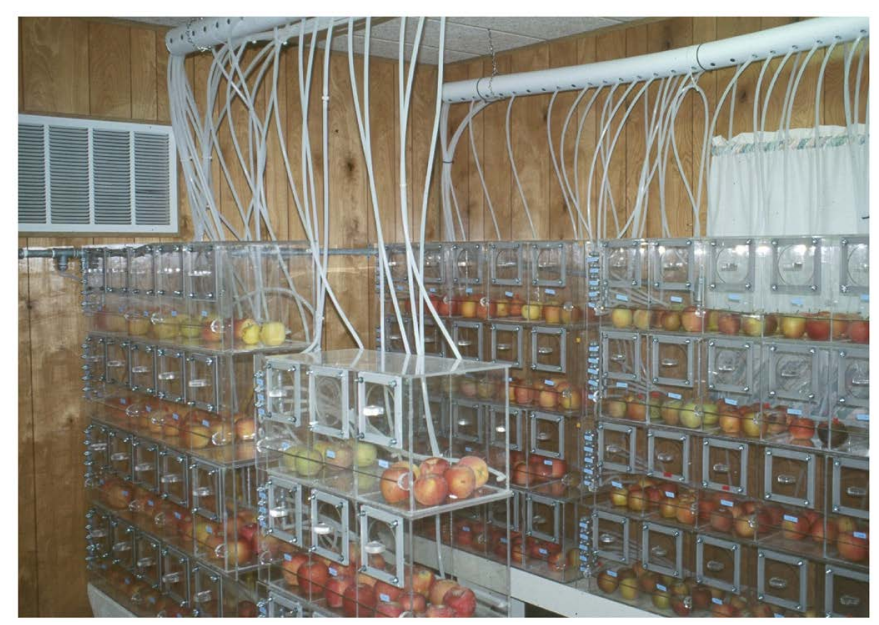

Figure 1. Ripening chambers at the University of Idaho Pomology and Viticulture Program laboratories were used to evaluate evolved ethylene and respiration of apples. 
The experimental design was a randomized complete block with seven composite replications. Assumption of normality was checked by computing univariate analyses for all treatments of this study. All data were normally distributed including percentages of sunburn rates. Data were analyzed by general linear analysis (GLM), using a t test and LSD mean separation $(P \leq 0.05)$, using SAS (SAS Institute Inc., Cary, NC).

\section{Results and Discussion}

"Red Spur Delicious" apple fruits from trees receiving Messenger ${ }^{\circledast}$ applications had significantly (about 23\%) better color than those from untreated control trees in 2011 (Table 1).

Application of Messenger ${ }^{\circledast}$ resulted in lower concentrations of $\mathrm{N}, \mathrm{Ca}, \mathrm{Mg}, \mathrm{K}$, and $\mathrm{Zn}$ but higher concentrations of $\mathrm{Fe}, \mathrm{Cu}$, and $\mathrm{Mn}$ in the fruit tissue of "Red Spur Delicious" in 2011, although differences were not always significant (Table 2). The lower concentrations of some fruit minerals in "Red Spur Delicious" apple, particularly $\mathrm{N}$, could have contributed to the better red color formation of fruit from the Messenger ${ }^{\oplus}$-treated trees [27].

Results for respiration and ethylene in "Red Spur Delicious" in 2011 are presented in Figure 2 and Figure 3. Messenger accelerated ethylene production during the initial three days of incubation in the ripening chambers. However, after the three measurements, no difference was observed in ethylene production between untreated control and Messenger ${ }^{\oplus}$-treated fruit (Figure 1). Messenger ${ }^{\circledR}$ consistently increased respiration rates of this apple at all measuring times (Figure 2). Nevertheless, this acceleration did not seem to adversely affect fruit firmness in "Red Spur Delicious" apple, which is a positive aspect of Messenger ${ }^{\oplus}$.

Table 1. Effects of Harpin protein (Messenger ${ }^{\circledR}$ ) on fruit quality at harvest and leaf weight and size in "Redspur Delicious" Apple in 2011.

\begin{tabular}{cccccccccc}
\hline Treatment & $\begin{array}{c}\text { Weight } \\
(\mathrm{g})\end{array}$ & $\begin{array}{c}\text { Color } \\
(1-5)^{\mathrm{z}}\end{array}$ & $\begin{array}{c}\text { Firmness } \\
(\mathrm{N})\end{array}$ & $\begin{array}{c}\text { Sol. } \\
\text { solids } \\
\left({ }^{\circ} \mathrm{Brix}\right)^{\mathrm{z}}\end{array}$ & $\begin{array}{c}\text { Starch } \\
(1-6)^{\mathrm{z}}\end{array}$ & $\begin{array}{c}\text { Leaf } \\
\mathrm{dwt} \\
(\%)\end{array}$ & $\begin{array}{c}\text { Leaf fwt } \\
(\mathrm{g} / \mathrm{leaf})\end{array}$ & $\begin{array}{c}\text { Leaf } \\
\mathrm{dwt}^{2} \\
(\mathrm{~g} / \mathrm{leaf})\end{array}$ & $\begin{array}{c}\text { Leafarea } \\
\left(\mathrm{cm}^{2} / \mathrm{leaf}\right)\end{array}$ \\
\hline Control & $214.9 \mathrm{a}^{\mathrm{y}}$ & $3.44 \mathrm{~b}$ & $71.54 \mathrm{a}$ & $12.02 \mathrm{a}$ & $3.25 \mathrm{a}$ & $36.51 \mathrm{a}$ & $0.86 \mathrm{a}$ & $0.31 \mathrm{a}$ & $28.58 \mathrm{a}$ \\
Messenger $^{\circledR}$ & $205.2 \mathrm{a}$ & $4.22 \mathrm{a}$ & $73.21 \mathrm{a}$ & $12.40 \mathrm{a}$ & $3.07 \mathrm{a}$ & $36.29 \mathrm{a}$ & $0.77 \mathrm{a}$ & $0.28 \mathrm{a}$ & $27.26 \mathrm{a}$ \\
\hline
\end{tabular}

${ }^{2}$ Fruit color ranking: $1=$ green, progressively to $5=$ uniform red; Sol. Solids $=$ soluble solids concentration; Starch: starch degradation pattern (SDP); $1=$ least starch degradation, progressively to $6=$ most starch degradation; fwt $=$ fresh weight; $\mathrm{dwt}=$ dry weight. ${ }^{{ }^{y}}$ Mean separation within each column by LSD at $5 \%$ level.

Table 2. Effects of Harpin protein (Messenger ${ }^{\circledast}$ ) on fruit dry weight and fruit mineral nutrient concentrations in "Red Spur Delicious" apple in 2011.

\begin{tabular}{cccccccccc}
\hline Treatment & $\begin{array}{c}\text { Dry wt. } \\
(\%)\end{array}$ & $\begin{array}{c}\mathrm{N} \\
(\% \mathrm{dwt})\end{array}$ & $\begin{array}{c}\mathrm{Ca} \\
(\mathrm{ppm})\end{array}$ & $\begin{array}{c}\mathrm{Mg} \\
(\%)\end{array}$ & $\begin{array}{c}\mathrm{K} \\
(\mathrm{ppm})\end{array}$ & $\begin{array}{c}\mathrm{Fe} \\
(\mathrm{ppm})\end{array}$ & $\begin{array}{c}\mathrm{Zn} \\
(\mathrm{ppm})\end{array}$ & $\begin{array}{c}\mathrm{Cu} \\
(\mathrm{ppm})\end{array}$ & $\begin{array}{c}\mathrm{Mn} \\
(\mathrm{ppm})\end{array}$ \\
\hline Control & $14.99 \mathrm{~b}^{\mathrm{z}}$ & $0.13 \mathrm{a}$ & $265 \mathrm{a}$ & $377 \mathrm{a}$ & $8651 \mathrm{a}$ & $6.63 \mathrm{a}$ & $2.74 \mathrm{a}$ & $2.98 \mathrm{a}$ & $2.04 \mathrm{a}$ \\
Messenger $^{\infty}$ & $15.49 \mathrm{a}$ & $0.10 \mathrm{a}$ & $239 \mathrm{~b}$ & $327 \mathrm{~b}$ & $8256 \mathrm{~b}$ & $8.12 \mathrm{a}$ & $2.10 \mathrm{~b}$ & $3.05 \mathrm{a}$ & $2.10 \mathrm{a}$ \\
\hline
\end{tabular}

${ }^{z}$ Mean separation within each column by LSD at $5 \%$ level; wt. = weight. 


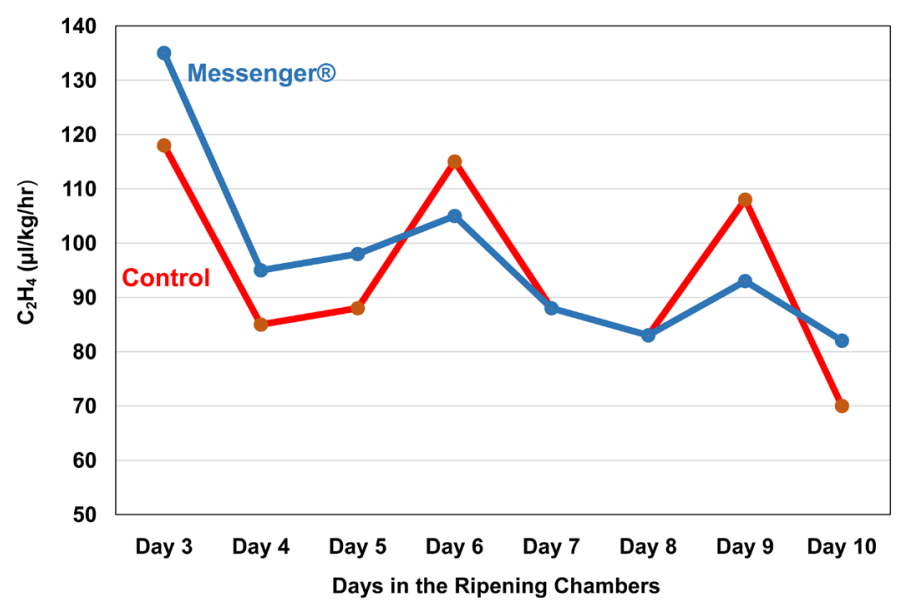

Figure 2. Trend of ethylene evolution in "Red Spur Delicious" apple in ripening chambers, after storage.

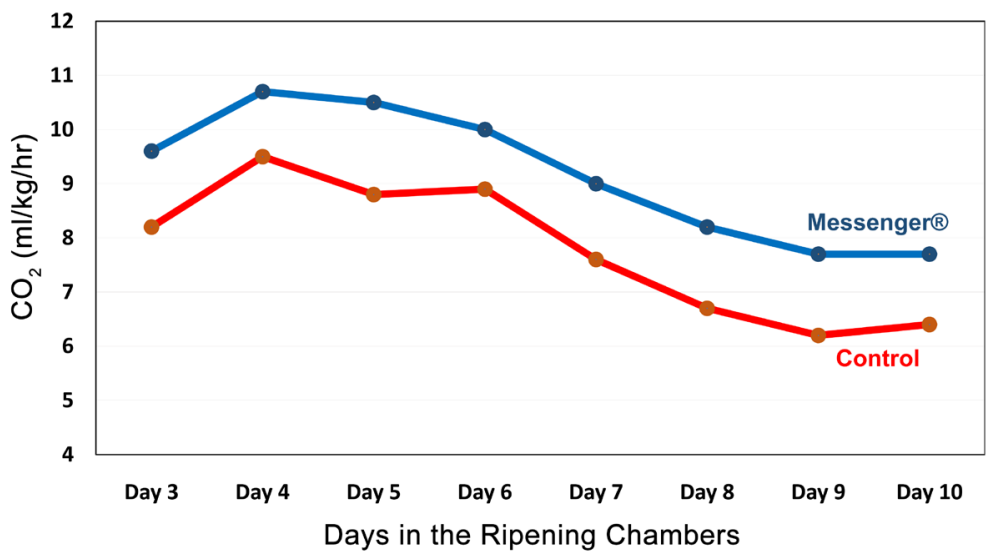

Figure 3. Trend of respiration in "Red Spur Delicious" apple in ripening chambers, after storage.

The impact of Messenger ${ }^{\circledast}$ application on fruit color in 2012 was mostly similar to the results in 2011. In 2012, "Red Chief Delicious" fruit from trees receiving Messenger ${ }^{\circledast}$ applications had significantly better color than those from untreated control trees in both Parma (Table 3) and Payette (Table 4) locations. Messenger ${ }^{\circledast}$ also reduced the percentage of "Red Chief Delicious" fruit with small unfinished red color in Parma orchard in 2012 (Table 3). Although Messenger ${ }^{\circledast}$ sprays improved fruit color in "Jonathan" and "Early Spur Rome" apples in 2012, differences were not significant (Table 4 and Table 5).

"Red Spur Delicious" was a popular "Delicious" apple and was widely planted in Idaho and other states in the Pacific Northwest in the 1980s, and many of these orchards still exist in the region. However, this apple is a poor-coloring cultivar, forcing growers to delay harvest to gain better color. This delay may enhance internal apple maturity and reduce storage life. Improving fruit color is arguably the most challenging issue for the apple growers in Washington and Idaho, USA, and many other apple-producing areas of the world. In 2011, improvement of fruit color in "poor-coloring" "Red Spur Delicious" apple, without 
Table 3. Effects of Harpin protein (Messenger ${ }^{\circledast}$ ) on fruit quality of "Red Chief Delicious" at Parma, Idaho in 2012.

\begin{tabular}{ccccccc}
\hline Treatment & $\begin{array}{c}\text { Weight } \\
(\mathrm{g})\end{array}$ & $\begin{array}{c}\text { Color } \\
(1-5)^{\mathrm{z}}\end{array}$ & $\begin{array}{c}\text { Firmness } \\
(\mathrm{N})\end{array}$ & $\begin{array}{c}\text { Sol. solids } \\
\left({ }^{\circ} \mathrm{Brix}\right)^{\mathrm{z}}\end{array}$ & $\begin{array}{c}\text { Starch } \\
(1-6)^{\mathrm{z}}\end{array}$ & $\begin{array}{c}\text { Unfinished red color } \\
(\%)\end{array}$ \\
\hline Control & $191.3 \mathrm{~b}^{\mathrm{z}}$ & $3.70 \mathrm{~b}$ & $80.69 \mathrm{a}$ & $12.03 \mathrm{a}$ & $2.01 \mathrm{~b}$ & $27.7 \mathrm{a}$ \\
Messenger $^{\infty}$ & $205.9 \mathrm{a}$ & $4.30 \mathrm{a}$ & $78.15 \mathrm{~b}$ & $11.52 \mathrm{a}$ & $2.22 \mathrm{a}$ & $21.5 \mathrm{~b}$ \\
\hline
\end{tabular}

${ }^{z}$ Fruit color ranking: 1 = green, progressively to 5 = uniform red; Sol. Solids = soluble solids concentration; Starch: starch degradation pattern (SDP); $1.2=$ least starch degradation, progressively to $6=$ most starch degradation. ${ }^{\mathrm{y}}$ Mean separation within each column by LSD at $5 \%$ level.

Table 4. Effects of Harpin protein (Messenger ${ }^{\circledR}$ ) on fruit quality attributes of "Red Chief Delicious" and "Jonathan" apples in Payette, Idaho in 2012.

\begin{tabular}{|c|c|c|c|c|c|c|c|}
\hline \multirow[b]{2}{*}{ Treatment } & \multicolumn{5}{|c|}{ Red Chief } & \multicolumn{2}{|c|}{ Jonathan } \\
\hline & $\begin{array}{c}\text { Weigh } \\
(\mathrm{g})\end{array}$ & $\begin{array}{l}\text { Color } \\
(1-5)^{\mathrm{z}}\end{array}$ & $\begin{array}{l}\text { Firmness } \\
(\mathrm{N})\end{array}$ & $\begin{array}{l}\text { Soluble solids } \\
\left({ }^{\circ} \mathrm{Brix}\right)^{\mathrm{z}}\end{array}$ & $\begin{array}{l}\text { Starch } \\
(1-6)^{z}\end{array}$ & $\begin{array}{c}\text { Weight } \\
\text { (g) }\end{array}$ & $\begin{array}{l}\text { Color } \\
(1-5)^{\mathrm{z}}\end{array}$ \\
\hline Control & $186.0 \mathrm{a}^{\mathrm{y}}$ & $3.40 \mathrm{~b}$ & $72.95 \mathrm{a}$ & $14.48 \mathrm{a}$ & $3.00 \mathrm{a}$ & $149.9 \mathrm{a}$ & $4.31 \mathrm{a}$ \\
\hline Messenger ${ }^{\circledast}$ & $198.4 \mathrm{a}$ & $3.85 \mathrm{a}$ & $72.59 \mathrm{a}$ & $13.88 \mathrm{a}$ & $2.78 \mathrm{a}$ & $119.7 \mathrm{~b}$ & $4.50 \mathrm{a}$ \\
\hline
\end{tabular}

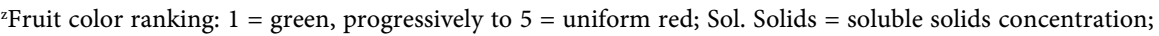
Starch: starch degradation pattern (SDP); $1.2=$ least starch degradation, progressively to $6=$ most starch degradation. ${ }^{\mathrm{y}}$ Mean separation within each column by LSD at $5 \%$ level.

Table 5. Effects of Harpin protein (Messenger ${ }^{\circledast}$ ) on fruit quality in "Early Spur Rome" apple in Payette, Idaho in 2012.

\begin{tabular}{ccccccc}
\hline Treatment & $\begin{array}{c}\text { Weight } \\
(\mathrm{g})\end{array}$ & $\begin{array}{c}\text { Color } \\
(1-5)^{\mathrm{z}}\end{array}$ & $\begin{array}{c}\text { Firmness } \\
(\mathrm{N})\end{array}$ & $\begin{array}{c}\text { Soluble solids } \\
\left({ }^{\circ} \text { Brix }\right)^{\mathrm{z}}\end{array}$ & $\begin{array}{c}\text { Starch } \\
(1-6)^{\mathrm{z}}\end{array}$ & $\begin{array}{c}\text { Water core } \\
(\%)\end{array}$ \\
\hline Control & $202.0 \mathrm{a}$ & $4.25 \mathrm{a}$ & $102.2 \mathrm{a}$ & $13.37 \mathrm{a}$ & $2.60 \mathrm{a}$ & $0.27 \mathrm{a}$ \\
Messenger $^{\oplus}$ & $203.6 \mathrm{a}$ & $4.54 \mathrm{a}$ & $99.3 \mathrm{a}$ & $13.27 \mathrm{a}$ & $2.90 \mathrm{a}$ & $0.23 \mathrm{a}$ \\
\hline
\end{tabular}

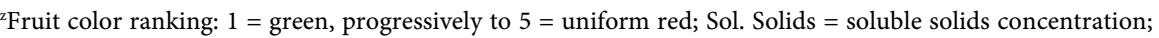
Starch: starch degradation pattern (SDP); 1.2 = least starch degradation, progressively to $6=$ most starch degradation. ${ }^{\mathrm{y}}$ Mean separation within each column by LSD at $5 \%$ level.

reduction of firmness or an increase in SDP with the use of Messenger ${ }^{\circledR}$ is an extremely positive aspect of this chemical. In this study, after storage, fruit color in trees receiving Messenger ${ }^{\circledR}$ was again higher than those the untreated control trees (data not shown).

In 2012, application of Messenger enhanced fruit maturity of "Red Chief Delicious" apple grown in Parma, as indicated by an increase in the fruit size and SDP in this cultivar (Table 3). It is noteworthy that application of Messenger tended to increase fruit weight in "Red Chief Delicious" in both locations and "Early Spur Rome" apples in 2012 but decreased fruit weight in "Jonathan" apples in 2012, although differences were not always significant. Based on this study, application of Messenger on "Jonathan" apple may not be advisable, as it reduced fruit size and did not significantly improve the fruit color in 2012. Further studies are warranted to investigate the influence of environmental interactions such as temperatures with different concentrations of Harpin protein and application times. 
Production of apples in any region must be planned based on a complete analysis of supply and market demand. Also, because of the competitive nature of apple global market, cost of production and thus, margin of profit should be carefully taken into account by apple producers. Application of pesticides, nutrients, water, and cost of training, thinning, harvesting, shipment and storage are among the essential expenses in fruit production. Many growers consider the application of bio-stimulants as a luxury practice and thus, are hesitant to use them unless proven absolutely beneficial and cost-effective. As an example, the use of Prolamin $\left(\mathrm{GA}_{4+7} \& \mathrm{BA}_{6}\right)$ is well documented to improve fruit shape by increasing fruit length to diameter ration [28] and it will consequently increase the net return to the apple growers.

Based on this study, Messenger ${ }^{\circledR}$ can certainly increase fruit color in different apple cultivars. However, a cost/benefit analysis on the use of Messenger ${ }^{\circledR}$ is essential for any apple grower. If apples are produced in high elevations with long warm days and cool nights, application of color-prompting agents may not be necessary, as such a region is usually inducive to the formation of fruit piments (author's unpublished data). Nevertheless, in cultivars that mature in August when minimum and maximum daily temperatures are high, and in apples that are produced in lower elevations, or in poor-coloring apples grown in any region, the use of Messenger ${ }^{\otimes}$ could lead to fruit color improvement, and thus economically justifiable. Further studies are required to investigate the impact of Messenger ${ }^{\oplus}$ on fruit quality under various temperatures and abiotic stress conditions.

\section{Acknowledgements}

The author wishes to express his gratitude to the Idaho Apple Commission and the Idaho Agricultural Experiment Station for their financial support of this project. Contributions of labor and materials by several Idaho fruit growing companies, including Henggeler Fruit Packing Co., and assistance of Ms. Bahar Fallahi and Mr. Michael J. Kiester in this project is gratefully appreciated.

\section{Conflicts of Interest}

The author declares no conflicts of interest regarding the publication of this paper.

\section{References}

[1] Hildebrand, E.M. (1944) The Mode of Action of the Pollenicide, Elgetol. Proceedings of the American Society for Horticultural Science, 45, 53-58.

[2] Fallahi, E. (1997) Application of Endothallic Acid, Pelargonic Acid, and Hydrogen Cyanamide for Blossom Thinning in Apple and Peach. HortTechnology, 7, 395-399. https://doi.org/10.21273/HORTTECH.7.4.395

[3] Fallahi, E., Williams, M.W. and Colt, W.M. (1997) Blossom Thinning of "Law Rome Beauty" Apple with Hydrogen Cyanamide and Monocarbamidedihydrogensulfate. Journal of Tree Fruit Production, 2, 33-44. 
https://doi.org/10.1300/J072v02n01_03

[4] Fallahi, E. and Willemsen, K. (2002) Blossom Thinning of Pome and Stone Fruit HortScience, 37, 474-476. https://doi.org/10.21273/HORTSCI.37.3.474

[5] Fallahi, E., Kilby, M. and Moon, J.W. (1990) Effects of Various Chemicals on Dormancy, Maturity and Thinning of Peaches. Deciduous Fruit and Nut. University of Arizona, College of Agriculture and Life Sciences, Tucson, Report Series No. 83, 121-128.

[6] Fallahi, E., Simons, B.R., Fellman, J.K. and Colt, W.M. (1992) Use of Hydrogen Cyanamide for Apple and Plum Thinning. Plant Growth Regular, 11, 435-439. https://doi.org/10.1007/BF00130653

[7] Fallahi, E., Lee, R.R. and Lee, G.A. (1998) Commercial-Scale Use of Hydrogen Cyanamide for Blossom Thinning of Apple and Peach. HortTechnology, 8, 556-560. https://doi.org/10.21273/HORTTECH.8.4.556

[8] Warner, G. (1998) Consistent Tonnage Needed for Profitability. Good Fruit Grower, 49, 9-10.

[9] Fallahi, E. (1998) The Use of Blossom Thinners for Regular Cropping Deciduous Fruit Trees. Proceedings of the Plant Growth Regulation Society of America, 27-33.

[10] Greene, D., Hauschild, W.K.I. and Krupa, J. (2001) Effect of Blossom Thinners on Fruit Set and Fruit Size of Peaches. HortTechnology, 11, 179-183.

https://doi.org/10.21273/HORTTECH.11.2.179

[11] Zhang, C. and Whiting, M.D. (2011) Improving "Bing” Sweet Cherry Fruit Quality with Plant Growth Regulators. Scientia Horticulturae, 127, 341-346. https://doi.org/10.1016/j.scienta.2010.11.006

[12] Proebsting, E.L., Carter, G.H. and Mills, H.H. (1973) Quality Improvement in Canned "Rainier" Cherries ( $P$. avium L.) with Gibberellic Acid. Journal of the American Society for Horticultural Science, 98, 334-336.

[13] Facteau, T.J., Rowe, K.E. and Chestnut, N.E. (1985) Firmness of Sweet Cherry Following Multiple Applications of Gibberellic Acid. Journal of the American Society for Horticultural Science, 110, 775-777.

[14] Kappel, F. and MacDonald, R.A. (2002) Gibberellic Acid Increases Fruit Firmness, Fruit Size and Delays Maturity of "Sweetheart" Sweet Cherry. Journal of the American Pomological Society, 56, 219-222.

[15] Kappel, F. and MacDonald, R.A. (2007) Early Gibberellic Acid Sprays Increase Firmness and Fruit Size of "Sweetheart" Sweet Cherry. Journal of the American Pomological Society, 61, 38-43.

[16] Clayton, M., Biasi, W.V., Agar, I.T., Southwick, S.M. and Mitcham, E.J. (2006) Sensory Quality of "Bing" Sweet Cherries Following Preharvest Treatment with Hydrogen Cyanamide, Calcium Ammonium Nitrate, or Gibberellic Acid. HortScience, 41, 745-748. https://doi.org/10.21273/HORTSCI.41.3.745

[17] Lenahan, O.M., Whiting, M.D. and Elfving, D.C. (2006) Gibberellic Acid Inhibits Floral Bud Induction and Improve "Bing” Sweet Cherry Fruit Quality. HortScience, 41, 654-659. https://doi.org/10.21273/HORTSCI.41.3.654

[18] Fontanilla, J.M., Montes, M. and De Prado, R (2005) Induction of Resistance to the Pathogenic Agent Botrytis Cinerea in the Cultivation of the Tomato by Means of the Application of the Protein "Harpin" (Messenger). Communications in Agricultural and Applied Biological Sciences, 70, 35-40.

[19] Wei, Z.M., Qiu, D., Kropp, M.J. and Schading, R.L. (1998) Harpin, an HR Elicitor, Activates Both Defense and Growth Systems in Many Commercially Important 
Crops. Phytopathology, 88, S96. (Abstr.)

[20] Zitter, T.A. and Beer, S.V. (1998) Harpin for Insect Control. Phytopathology, 88, S104-S105. (Abstr.)

[21] de Capdeville, G., Beer, S.V., Watkins, C.B., Wilson, C.L., Tedeschi, L.O. and Aist, J.R. (2003) Pre- and Post-Harvest Harpin Treatments of Apples Induce Resistance to Blue Mold. Plant Disease, 87, 39-44. https://doi.org/10.1094/PDIS.2003.87.1.39

[22] Fontanilla, M., Montes, M. and De Prado, R. (2005) Effects of the Foliar-Applied Protein "Harpin" (Messenger) on Tomatoes Infected with Phytophthora Infectants. Communications in Agricultural and Applied Biological Sciences, 70, 41-45.

[23] de Capdeville, G., Beer, S.V., Watkins, C.B., Wilson, C.L. and Aist, J.R. (2001) Harpin-Induced Resistance for the Control of Blue Mold of Apples. Phytopathology, 91, S166. (Abstr.)

[24] de Capdeville, G., Beer, S.V., Wilson, C.L. and Aist, J.R. (2002) Alternative Disease Control Agents Induce Resistance to Blue Mold in Harvested "Red Delicious" Apple Fruit. Phytopathology, 92, 900-908. https://doi.org/10.1094/PHYTO.2002.92.8.900

[25] Chalker-Scott, L. (2021) The Myth of the Magic Bullet, Success in the Lab Guarantees Success in the Field. https://s3.wp.wsu.edu/uploads/sites/403/2015/03/harpin.pdf

[26] Taylor, L. (2020) Crop Protection Guide for Tree Fruits in Washington 2020/2021. https://pubs.extension.wsu.edu/2019-crop-protection-guide-for-tree-fruits-in-washi ngton

[27] Fallahi, E., Fallahi, B. and Kiester, M.J. (2018) Evapotranspiration-Based Irrigation Systems and Nitrogen Effects on Yield and Fruit Quality at Harvest in Fully Mature "Fuji" Apple Trees over Four Years. HortScience, 53, 38-43. https://doi.org/10.21273/HORTSCI12393-17

[28] Burak, M. and Buyukylmaz, M. (1998) Effect of Promalin on Fruit Shape and Quality of "Starking Delicious" Apple Cultivar. Acta Horticulturae, 463, 365-369. https://doi.org/10.17660/ActaHortic.1998.463.46 